\title{
Team Ministry between Pastors and Shepherdesses: A Case Study of the Seventh Day Adventist Midlands Conference
}

\begin{abstract}
Linda Sibanda
Adventist University of Africa, Theological Seminary, Zambia

*Corresponding Author: Linda Sibanda, Adventist University of Africa, Theological Seminary, Zambia

Abstract: The purpose of this study was to develop, implement and evaluate an initiative that would promote pastoral teamwork in pastoral families in Midlands Conference in Zambia's Seventh Day Adventist (SDA) Church. In the Midlands Conference it has been noted that a few number of shepherdess are involved in team ministry with their husbands. After reviewing the literature on teamwork in the Old Testament and the New Testament as well as in other Christian writings, the researcher developed in intervention strategy based on the theological and literature review of this project. The purpose was to equip and empower the shepherdess for effective team work ministry. The population was made up of 34 pastors and 34 shepherdesses in the Midlands Conference for the year 2015. Data was gathered using questionnaires prepared by the researcher. The findings were analysed using SPSS 23.0 and thematically. The study revealed that there is need for a team ministry program. The researcher therefore embarked on an intensive training program to impart knowledge, skills and practices to the shepherdesses. The development and implementation of this program was done in the period starting from January 2016 to February 2017, seven lessons were given in training seminars. The evaluation of this program has shown an overall positive change of shepherdess in team work. In view of the results obtained from this study, it was recommended that the Midlands Conference shepherdesses should prepare and organize ongoing educational programs to equip and empower the shepherdesses so as to enable them to perform efficiently in team ministry with their husbands.
\end{abstract}

Keywords: Encouragement, Team, Ministry, Pastors, Shepherdesses, Midlands, Conference

\section{INTRODUCTION}

The church has a big responsibility to prepare people for the coming of Jesus Christ. It exists for the purpose of giving service towards the salvation of people. So it evangelizes in many different ways. Those who accept the word are taught and baptized in the name of the three members of the holy trinity. Jesus commanded his disciples to, "Go into the world and teach all nations baptizing them in the name of the father, the Son and the Holy Ghost". (Matt 28:19). The same commission is also repeated in the book of (Mark 16:15). Luke further substantiates that, "And that repentance and remission of sins should be preached in his name among all nations, beginning at Jerusalem". (Luke 24:47). So there is work to spread the gospel ministry. In this work the trinity works as a team.

The Seventh -day Adventist church has taken the responsibility of spreading the gospel to the entire world. This is done through various forms of evangelism including that of teamwork. Jesus valued teamwork in his ministry and showed no partiality between people. This is implied in the composition of his team. There were both men and women of different backgrounds and status quo in this team (Luke 8:1-3). Among them was Joanna the wife of Chuza Herod's steward. She may be considered as belonging to a higher status quo. Others are mentioned with no positions attached; possibly because they were common people including Mary Magdalene called by the name of the city of her previous prostitution. Ellen white says that Magdala was, "... at the southern end of the plain of Gennesaret" (Roberts, 2012).

There is also two by two team ministry exercised by Jesus to spread the gospel. Jesus “... appointed other seventy also and sent them two by two before his face into every city and place whither himself would come" (Luke 10:1). On the same vein there is also a call to ministry of husbands and wives. So many biblical couples have worked together as a team in God's work beginning with the team of Adam and Eve (Gen 1:28)and even in the early church the team/couple of Aquila and Priscilla (Acts 
18:26). In view of all the above, everyone has been called to the ministry. This is supported by (Ephesians' 4:1) in which Paul beseeches that,““'ye walk worthy of the vocation where with ye are called." This call includes pastors and shepherdesses. For this reason the Seventh Day Adventist (SDA) church encourages team work between pastors and shepherdesses. The pastors and shepherdesses under Midlands Zambia conference are also part of this unique team ministry.

The pastors and shepherdesses are supposed to work together as a team to make the ministry more effective. Obviously two are better than one. Ellen White said that when possible let the minister and spouse work together (Roberts, 2012). One would say that this is a biblical concept to be studied and emulated. The pastors and shepherdesses in Midlands Zambia Conference have a responsibility to work together as a team to evangelize the Zambian community and abroad.

It should be noted that when divided the pastor and shepherdess may not minister effectively. When united the ministry may be enhanced. Hence the need for team ministry among pastors and shepherdesses in Midlands Conference.(Dan and Gloria, 2005)wrote that what is needed in ministerial families is for the husband and wife to be united in their vision and in sharing the unique mission of the Adventist church and ministry. When this is accomplished the ministry will be greatly improved.

\subsection{Description of the Ministry Context}

The Midlands Zambia Conference where the study was carried out has its headquarters in Kabwe, the central province of Zambia. This conference oversees the churches that are located in Lusaka and Central provinces. These churches are grouped into districts. The current number of districts is 34 . There is a total number of 458 churches and 494 companies. The total membership of these churches is 242,709 members.

The area has 34 Pastors of which 22 are young couples with less than 15years in marriage. Twelve ministers are above 15 years in marriage. The pastors do the preaching, visitations, counseling, conducting seminars and other church duties. On the other hand the shepherdesses spend their time doing household chores. Needless to say, sometimes their time may be spent in chatting with neighbors. Some shepherdesses are employed. However, when they are not at work they seem to follow the pattern of the shepherdesses who are housewives. Being one of the shepherdesses, is my privilege to get interested in betterment of Pastoral families. In addition to that, my professional calling being a lecturer at Rusangu University in Zambia brings me to a desire to teach others about teamwork.

\section{Statement of the Problem}

The lack of teamwork among pastors and their spouses has a negative impact on the ministry. It creates an atmosphere of division in the family that affects God's work. The pastors usually minister alone and the shepherdesses complain that their husbands do not involve them. There is therefore a great need to know the root cause of the lack of team ministry between ministers and their spouses.

\section{Statement of Purpose}

The purpose of this dissertation is to develop, implement and evaluate an initiative that would promote teamwork in pastoral families in Midlands Conference. It is the greatest purpose of this study to come up with a strategy with an aim for helping the pastors and shepherdesses to be equipped and empowered in working together as a team. Teamwork is very important in improving pastoral ministry. It also adds to the growth of the church.

\section{JUSTIFICATION}

In view of the increasing trend of lack of involvement of shepherdesses in ministry in the SDA Church in Central Zambia Conference a study was done. This is not only in agreement with 'In the Spirit of Prophecy' where teamwork is encouraged through the works of Ellen G. White and James White (White, 2005)but in line with what the bible shows as in Acts A team ministry has a support in the Bible as revealed in Rom 16:3 through the teamwork of Priscilla and Aquila who were workers together with Paul. 
Team Ministry between Pastors and Shepherdesses: A Case Study of the Seventh Day Adventist Midlands Conference

\section{SIGNIFICANCE OF THE STUDY}

This study might contribute to the growth of the church in Midlands Conference and other Churches in the following ways.

1. Undertaking this study is likely to equip and empower the ministers to minister effectively with their spouses.

2. Hopefully the study hopes create an awareness of the unique challenges of shepherdesses and provide solutions to alleviate them.

3. Furthermore, the implementation of the proposed program is likely to position the ministers and the shepherdesses for spiritual growth.

4. The process of this study might provide a model of ministry that will enhance God's work.

\subsection{Delimitation}

The implementation and evaluation of the program will be limited to one year to give ample time for data analysis and evaluation as well as writing of the dissertation. Midlands Conference is the area where this dissertation will be carried out because it seems to be weak in team ministry. The focus will be on pastors and their wives. Other ministers and their spouses in other conferences are left out because of the broadness of the scope of work to be done. In addition, there is need to improve teamwork in Central Zambia Conference.

\section{ROLE OF TEAMWORK FOR ORGANIZATION EFFECTIVENESS}

Many businesses rely on successful teamwork to reach company goals and objectives. The church as an organisation is not an exceptional to use teamwork for effective ministry. Teamwork plays a vital role in organizational effectiveness, which determines how effective a church can be in its many facets (Gibson and Gibbs, 2006). These facets can include internal communication among members (pastor and shepherdess or wife) in the team, communication with members of the church and the service they provide to the members of the church. Depending on the nature of the church activities, the pastor and the wife can work as a team to ensure that these facets are conducted successfully. This way, a pastor alone or poorly functioning pastor and wife will be unable to guarantee a ministry's effectiveness.

The more pastor and wife in the church are working together as a team toward church growth, the more likely that goals of the church shall be met successfully. With varying skill sets, strategies, education levels and past work experiences of the pastor and the wife, such a team can bring more shared knowledge to the table in terms of innovation, ideas and solutions. This may result in better ministry and church growth.

With the pastor and shepherdess working together as a team, the church can benefit from the shared knowledge and decision-making can become more streamlined, since the decision will be more wellinformed over one that is made by just the pastor and this will even bring strong bond to the family of the pastor. This can translate to faster solutions to problems that may arise within the church, better response time even when the pastor is away (Hon, 2008).

The strength of having the pastor and the wife working together is for a common purpose of ministry and this can help the shepherdess to grow also in doing ministry. This purpose is most often the success as it improves corporation, which drives morale (Carson, Tesluk and Maron, 2007). This recognition of common purpose and the daily striving of working together of the pastor and wife will be for the greater good of the church's health, vitality and agility of a well-functioning organisation. The members of the church will also learn a lot from such team work.

\section{COMPONENTS OF TEAM EFFECTIVENESS}

Meuse (2009) recommended T - 7 Model for teamwork for effective organizational growth using different seven (7) components of team effectiveness. It has assumed that if these components are well applied, then the teamwork even of the pastor and wife in ministry for church growth can be effective. These components are; 
i. The motive - Both the Pastor and the Shepherdess must have the desire to work together in ministry. In addition, the church organization should agree and accept that both the pastor and the wife shall be allowed to do ministry with their support.

ii. Trust - For teamwork to properly work well, it is important that both parties trust one another (Austin, 2003). The pastor must trust the wife and the wife must trust the husband in doing ministry. If the two do not trust each, there cannot be any church growth.

iii. Personal skills - It is important to note that each person has different skills (Yoon, Song, Lim and Joo, 2010). The pastor has his own skills which might be limited so the addition of the skills of the wife can be reinforced. This can contribute to church growth of the SDA church.

iv. Competencies - apart from the skills, since each one is trained in different area of specialization, they can bring into ministry different competencies. The different competencies can add value to church growth. The study showed that both pastors and wives were trained in different fields which is an added advantage to the church of SDA.

v. Readiness of the team leader - It is of great importance that the pastor who is a team leader in this case must be willing to work with his wife in ministry. In this study, it showed that pastors were very willing and happy to work with their wives in ministry. If the pastor accommodates the wife in ministry, this can bring a positive change in the church for church growth.

vi. Organizational support - Since the pastor and the wife will work within the church organization, it is important that the membership and the church structures support the pastor and the shepherdess in ministry. Without their support it can be very difficult for the two to work well.

vii. Organizational resources - The church need to come up with a clear policy on how the two are to be supported for ministry. Since both shall be actively involved, it will be great to empower the two to motivate them for ministry.

\section{Methodology}

Qualitative and quantitative methods were used in this research. The qualitative approach takes into consideration the experiences of the people from their own perspectives (Roberts, 2012). It also gives room for detailed description of actions and behaviours of people. This method also brings to the surface what the pastors and shepherdesses feel about team ministry. Their knowledge and opinions are also brought out. Furthermore, the pastors and their spouses are assisted to improve on their weaknesses and even their strengths are also recognized. The information given by the respondents is shown through tables. In order to assist in the analysis, the percentages are also given.

The questionnaires used were the closed ended and open ended questions. These were given out so that the pastors and shepherdesses would be able to share their views in a better way. The advantage of open ended questions is that they enable the respondents to share their deeper thoughts from the bottom of their hearts, the questionnaire for the pastors comprised of 14 questions while that for shepherdesses had 15 questions. The researcher had two questionnaires. One contained questions about the demographic information and the background information of the respondents while for the other questionnaire was meant to find out if the pastors and shepherdesses are practicing team ministry.

Personal observation was used by the researcher so as to get more data. Being a shepherdess leader for Midlands Conference, Lusaka Zone, the researcher was able to observe what was happening among pastors and shepherdesses regarding team ministry. Data was also obtained from the statistical reports and some documents from the conference secretary.

\section{FINDINGS AND DISCUSSIONS}

\subsection{The Demographic Profile of the Shepherdesses}

The demographic profile of the shepherdesses shows that there were two shepherdesses who were above 60 years, fifteen were between $41-60$ years, twelve were between $30-34$ years and five were below 30 years. With regard to marital status, it was revealed that all the shepherdesses were married. 
Team Ministry between Pastors and Shepherdesses: A Case Study of the Seventh Day Adventist Midlands Conference

With regard to experience, there was no shepherdess who had experience less than two years, four had worked for three years, six for had worked for four years and five had worked for twenty years and above.

Table1. Demographic Profile of Shepherdesses

\begin{tabular}{|l|l|l|c|}
\hline Description & Category & Frequency & Percentage \\
\hline \multirow{4}{*}{ Age } & Above 60 & 2 & 6 \\
\cline { 2 - 4 } & $41-60$ & 15 & 44 \\
\cline { 2 - 4 } & $30-40$ & 12 & 34 \\
\cline { 2 - 4 } & Below 30 & 5 & 16 \\
\hline Marital status & Married & 34 & 0 \\
\hline $\begin{array}{l}\text { Experience as } \\
\text { shepherdess }\end{array}$ & 1 year & 0 & 0 \\
\cline { 2 - 4 } & 2 years & 4 & 12 \\
\cline { 2 - 4 } & 3 years & 6 & 59 \\
\cline { 2 - 4 } & 4 years & 20 & 18 \\
\hline
\end{tabular}

Source: Field Data, 2019

\subsection{The Demographic Profile of the Pastors}

The demographic profile of the pastors shows that there are three pastors above 60 years, 15 pastors between 41-60 years. Seven pastors between 30-40 years and five pastors below 30 years. These results indicate that there are three elderly pastors followed by middle age pastors who are 15 in number. This is a positive note in the sense that the midlands conference has many mature pastors who can give mature guidance and counsel to the young ones who are between 30-40 years and the latter category of pastors below 30 years. Therefore, the Midlands conference is blessed with many pastors capable of advancing the kingdom of God.

The implication of this study is that the church can also benefit from the ministry of the pastors of a various age groups. In addition, if well trained and equipped in team ministry, both the experienced and the young pastors will serve the church very well.

20 pastors out of 34 have five years and above in ministry. Six have been in ministry for four years. Four pastors have three years in ministry. The majority of the pastors have a lot of experience in ministry. They will be able to guide and counsel the young ministers who have less experience. Furthermore, the experience of the majority of the pastors will be of benefit in equipping and empowering the pastors for team ministry. So together, the experienced and less experienced will benefit from the training on team ministry.

Table2. Demographic Profile of Pastors

\begin{tabular}{|l|l|l|l|}
\hline Description & Category & Frequency & Percentages \\
\hline Age & Above 60 Years & 3 & 9 \\
\hline & 41-60 Years & 15 & 44 \\
\hline & $30-40$ Years & 16 & 47 \\
\hline & Below 30 Years & 0 & 0 \\
\hline Marital status & Married & 34 & 100 \\
\hline Experience as apastor & 1 year & 0 & 0 \\
\cline { 2 - 4 } & 2 years & 0 & 0 \\
\cline { 2 - 4 } & 3 years & 4 & 12 \\
\cline { 2 - 4 } & 4 years & 6 & 18 \\
\cline { 2 - 4 } & 5 years and above & 24 & 70 \\
\hline
\end{tabular}

Source: Field Data, 2019

\subsection{Challenges Faced by Pastors}

The findings as revealed by Table 3below revealed that a good number (47\%) of the pastors experienced no challenges with their spouses whilst $27 \%$ of the pastors were of the view that they had limited women affair programmes, 9\% felt that personality and opinion differed, $12 \%$ indicated that they encountered challenges when domestic pressures interfered with God's work and $6 \%$ felt that 
Team Ministry between Pastors and Shepherdesses: A Case Study of the Seventh Day Adventist Midlands Conference

because their spouses were busy with their own work. Therefore, these findings imply that the majority of the pastors encounter challenges with their spouses in regard to ministry work. These findings are congruent to the findings revealed in Roberts (2012) that most pastors encounter challenges with their wives and more need to be done to help them as they help the church members.

Table3. Challenges faced by pastors

\begin{tabular}{|l|l|l|}
\hline Challenges faced by pastors & Frequency & Percent \\
\hline Limited women affairs programmes & 9 & 27 \\
\hline No challenge & 16 & 47 \\
\hline Personality and opinion differ & 3 & 9 \\
\hline when domestic pressures interfere with God' work & 4 & 12 \\
\hline Because their spouse are busy with her work & 2 & 6 \\
\hline Total & $\mathbf{3 4}$ & $\mathbf{1 0 0}$ \\
\hline
\end{tabular}

Source: Field Data, 2019

\subsection{Challenges Faced by Shepherdess Concerning Team Work}

The findings of the study from the shepherdesses on challenges encountered with regard to team work revealed that $18 \%$ of the shepherdesses encountered no challenges, $62 \%$ indicated that the challenge was lack of team work, $12 \%$ felt that the challenge was not knowing what to do sometimes and $9 \%$ were of the view that time factor was the main challenge encountered.

For a team ministry to be effective the pastor and spouse should be able to relate well one with another thus being engaged in a healthy marriage. So a healthy marriage is cardinal to an effective team ministry. An effective team ministry begins with a health marriage and family grounded in a whole and holy relationship to the father through Jesus Christ and empowered by the Holy Spirit. Schmidt Latonia in White agrees by saying that being effective at work or in ministry begins by being effective at home (White, 2007). Those desiring to have an effective team ministry need to learn to relate well one with another in their marriage relationship.From the findings, therefore, all the necessary components that promote team work must be worked so that the ministry can achieve its intended purposes.

Table4. Challenges faced by shepherdess concerning team work

\begin{tabular}{|l|r|r|}
\hline Challenges faces shepherdess & \multicolumn{1}{|c|}{ Frequency } & \multicolumn{1}{c|}{ Percent } \\
\hline No challenge & 6 & 18 \\
\hline No team work & 21 & 62 \\
\hline Not knowing what to do sometimes & 4 & 3 \\
\hline time factor & 3 & 12 \\
\hline Total & $\mathbf{3 4}$ & 9 \\
\hline
\end{tabular}

Source: Field Data, 2019

\subsection{Shepherdesses' and Pastors' Responses on how Beneficial it would be to the Church if they Worked together with Pastors}

Table5. Shepherdesses and Pastors responses on how beneficial it would be to the church if they worked together with shepherdesses

\begin{tabular}{|l|l|l|l|}
\hline & Response & Frequency & Percentage \\
\hline Shepherdesses & Yes & 34 & 100 \\
& No & 0 & 0 \\
\hline Pastors & Yes & 34 & 100 \\
& No & 0 & 0 \\
\hline
\end{tabular}

Source: Field Data, 2019

Equally when the shepherdesses were asked on how beneficial to the church if they worked together as a team, the finding revealed that all the respondents were for the idea of working together representing a $100 \%$ response. 
Team Ministry between Pastors and Shepherdesses: A Case Study of the Seventh Day Adventist Midlands Conference

\subsection{Areas where Pastors thought Shepherdesses could be Involved to Assist in the Ministry}

With regard to areas where Pastors thought Shepherdesses could be involved to assist in the Ministry as shown in table 5 below, the findings revealed that the majority of respondents $51 \%$ were of the view that they should be involved in skills training and counseling, $18 \%$ indicated that they should be involved in issues of women and children, $27 \%$ felt that they should be involved in teaching and preaching and $6 \%$ indicated that they should be involved in hospitality and singing.

Table6. Areas where Pastors thought Shepherdesses could be involved to assist in the Ministry

\begin{tabular}{|l|l|l|}
\hline Areas where Shepherdesses should be involved & Frequency & Percent \\
\hline Teaching bible study & 2 & 6 \\
\hline Teaching and preaching & 9 & 27 \\
\hline Issues of women and children & & \\
\hline Skills Training and counseling & 6 & 18 \\
\hline Total & 17 & 51 \\
\hline
\end{tabular}

Source: Field Data, 2019

\subsection{Pastors Views on whether the Shepherdess was Doing Enough to Assist them in the Ministry}

It was observed that the majority of the pastors (65\%) felt that shepherdesses were not doing enough to assist them in the ministry while $35 \%$ were of the view that shepherdesses were doing enough to assist them in the ministry.

Table7. Pastors views on whether the shepherdesses were doing enough to assist them in the ministry

\begin{tabular}{|l|l|l|}
\hline Pastor's views & Frequency & Percent \\
\hline Yes & 12 & 35 \\
\hline No & 22 & 65 \\
\hline Total & 34 & 100 \\
\hline
\end{tabular}

Source: Field Data, 2019

\subsection{Areas Shepherdesses thought they could be Empowered to Assist in the Ministry}

With regard to areas the shepherdess thought they can be empowered to assist in ministry as shown in Table 7 below, the study revealed that $6 \%$ of the respondents were of the view that by educating people about the importance of the kingdom, $18 \%$ felt that by doing some community services, $15 \%$ of the respondents indicated that by being empowered financially, $6 \%$ were of the view that by being involved in team work, $21 \%$ indicated that by attending seminars they can help in the ministry. On the other hand, $27 \%$ felt that through training and team work, they can be empowered to assist in ministry and $9 \%$ were of the view that by working with the pastors, they can be empowered to assist in ministry.

Table8. Areas shepherdesses thought they could be empowered to assist in the ministry

\begin{tabular}{|l|r|r|}
\hline & Frequency & \multicolumn{1}{|c|}{ Percent } \\
\hline By educating people about the importance of the kingdom & 2 & 6 \\
\hline Doing some community services & 6 & 18 \\
\hline Financially & 5 & 15 \\
\hline Involving in team work & 2 & 6 \\
\hline Seminars & 7 & 21 \\
\hline through training and team work & 9 & 27 \\
\hline working with the pastor & 3 & 9 \\
\hline Total & $\mathbf{3 4}$ & $\mathbf{1 0 0}$ \\
\hline
\end{tabular}

Source: Field Data, 2019

\subsection{Pastors' Views on what should be Done to Improve the Ministry}

In regard to what should be done to improve the ministry, pastors were asked to state their views and the findings revealed that the majority $(61 \%)$ of the respondents were of the view that funds should be allocated for team ministry not only pastors, $27 \%$ indicated that there should be a deliberate policy to empower shepherdesses and $12 \%$ felt that Provide more training and seminars. 
Team Ministry between Pastors and Shepherdesses: A Case Study of the Seventh Day Adventist Midlands Conference

Table9. Pastors' views on what should be done to improve the ministry

\begin{tabular}{|l|l|l|}
\hline Pastors' views & Frequency & Percent \\
\hline A deliberate policy to empower shepherdesses & 9 & 27 \\
\hline funds should be allocated for team ministry not only pastors & 21 & 61 \\
\hline Provide more training and seminars & 4 & 12 \\
\hline Total & 34 & 100 \\
\hline
\end{tabular}

Source: Field Data, 2019

\subsection{Pastors Responses on whether the Shepherdesses Shared the Same Vision with Them}

The study as indicated in table 8 below revealed that the majority $59 \%$ of the respondents agreed that they shared the same vision because anything wrong affects shepherdesses and anything right also affected them and $41 \%$ felt that they did not share the same vision with shepherdesses.

Table10. Pastors Responses on whether the shepherdess shared the same vision with them

\begin{tabular}{|l|l|l|}
\hline Pastor's views & Frequency & Percent \\
\hline Don't share the same vision. & 14 & 41 \\
\hline Shared the vision & 20 & 59 \\
\hline Total & 34 & 100 \\
\hline
\end{tabular}

Source: Field Data, 2019

\subsection{Pastors' Views on the Roles the Shepherdesses can Do to Support the Ministry}

The findings as shown in table 9 below revealed that the majority $53 \%$ of the pastors were of the idea that shepherdesses should be supporting staff to their husbands, $41 \%$ felt that shepherdesses should be providing counseling especially on women's affairs and youths and $6 \%$ were of the view that shepherdesses should be involved in local church programmes with the pastors.

Table11. Pastors' views on the roles the shepherdesses can do to support the ministry

\begin{tabular}{|l|l|l|}
\hline Pastors' views & Frequency & Percent \\
\hline Be involved in local church programmes with the pastor & 2 & 6 \\
\hline providing counseling especially on women's affairs and youths & 14 & 41 \\
\hline to be a supporting staff to the husband & 18 & 53 \\
\hline Total & 34 & 100 \\
\hline
\end{tabular}

Source: Field Data, 2019

\subsection{Shepherdesses' Response on what Should be done to Improve Team Ministry}

Team ministry is very important in achieving the goal of the church and in trying to establish on what should be done to improve team ministry, the findings from the shepherdesses as shown in table 3 above, revealed that $32 \%$ were of the view that Shepherdesses and pastors should be praying and encouraging each other, $18 \%$ felt that more teachings and seminars should be conducted, and $50 \%$ were of the view that Shepherdesses and pastors should be working together.

Table12. Shepherdesses' response on what should be done to improve team ministry

\begin{tabular}{|l|r|r|}
\hline Shepherdesses' views & Frequency & Percent \\
\hline $\begin{array}{l}\text { Shepherdesses and pastors should be praying and encouraging } \\
\text { each other }\end{array}$ & 11 & 32 \\
\hline More teachings and seminars & 6 & 18 \\
\hline Shepherdesses and pastors should be working together & 17 & 50 \\
\hline Total & $\mathbf{3 4}$ & $\mathbf{1 0 0}$ \\
\hline
\end{tabular}

Source: Field Data, 2019

\subsection{Pastors Responses on the Shepherdess Involvement in the Ministry whether tt could Destroy the Family Values}

The findings revealed that the majority $68 \%$ of the respondents were of the view that shepherdess involvement in the ministry cannot destroy the family values and $32 \%$ felt that shepherdess involvement in the ministry can destroy the family values because as a mother she will not be there to look after the family since the pastor is a busy person. 
Team Ministry between Pastors and Shepherdesses: A Case Study of the Seventh Day Adventist Midlands Conference

Table13. Pastors responses on the shepherdess involvement in the ministry whether it could destroy the family values

\begin{tabular}{|l|l|l|}
\hline Pastors responses & Frequency & Percent \\
\hline No at all & 23 & 68 \\
\hline $\begin{array}{l}\text { yes because as a mother she will not be there to look after } \\
\text { the family since the pastor is busy }\end{array}$ & 11 & 32 \\
\hline & 34 & 100 \\
\hline
\end{tabular}

Source: Field Data, 2019

\section{CONCLUSION}

The study revealed that the majority of the pastors experienced no challenge and only a few had challenges. On the other hand, many of the shepherdesses encountered challenges I participating in team and only a few had no challenges. The finding revealed that all the respondents were for the idea of working together as a team. In regard to areas where Pastors thought Shepherdesses could be involved to assist in the Ministry, the findings revealed that the majority of respondents were of the view that they should be involved in skills training and counseling, while others indicated that they should be involved in issues of women and children, others felt that they should be involved in preaching and teaching and some indicated that they should be involved in hospitality and singing.

It was also observed that the majority of the pastors felt that shepherdess were not doing enough to assist them in the ministry. In regard to what should be done to improve the ministry, pastors were asked to state their views and the findings revealed that the majority of the respondents were of the view that more trainings and seminars should be provided.

Furthermore, the findings revealed that the majority of the respondents were of the view that shepherdess involvement in the ministry cannot destroy the family values.

\section{RECOMMENDATIONS}

1. There is great need for an implementation of an intervention project that will lead to the equipping and empowering pastors and shepherdesses, from Midlands Conference in team ministries. It is important to equip and empower the shepherdesses in team ministry so that they can deliver their services effectively.

2. Team ministry between the pastors and shepherdesses in Midlands Conference should be increased.

\section{REFERENCES}

Austin, C. (2003). Transactive memory in organizational groups: The effects of content, consensus, specialization and accuracy on group performance. J.Appl. Psychol., 88: 886-878.

Bentzinger, D. and Bentzinger G. (2005). Team ministry: A shepherdess international resource for ministry spouses. The journal. 19 (3) $1-24$.

Carson, J. B., Tesluk, P. E. and Maron, J. A (2007). Shared leadership in teams: An investigation of antecedent conditions and Performance. Acade.Manage. J., 50: 1217 - 1234.

Gibson. J. B. and Gibbs, J. L. (2006). Unplacking the concept of virtuality: The effects of Georgraphic dispersion, electronic dependence, dynamic structure and national diversity on team innovation. Admin. Sci. Quart. 51: $451-495$.

Hon, H. Y. (2008). When creativity requirement does not enhance employee creativity: The limits of goal directed behavior. PhD Thesis, Hong Kong, Baptist University, Hong Kong.

Meuse, K. P. D. (2009). Driving team effectiveness: A comparative analysis of the Korn - Ferry T7 Model with popular models. Korn Ferry Inst. 1: 1 - 16

Roberts, C. M. (2012).The Dissertation Journey: A Practical and Comprehensive Guide to Planning, Writing and Defeanding, $2^{\text {nd }}$ ed Thousand Oaks, CA: Corwin

White, E. G. (2005).Life Sketches of Ellen, London, Stanborough.

White,E.G (2007). The Desire of Ages. London, Stanborough.

White,E.G (2007). Evangelism London, Stranborough 


\section{AUTHOR's BIOGRAPHY}

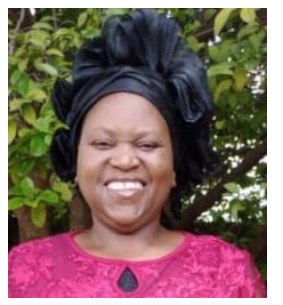

Linda Sibanda, is an an academician. She did a diploma in Primary Education at Gwanda Zintec College in Zimbabwe. Bachelor of Education in Religious Studies at Solusi University. Bachelor of Arts in Theology at Solusi University and Masters of Art in Religious Education at Solusi University. Currently she is pursuing a Doctor of Ministry Degree at Adventist University of Africa in Kenya. She taught at Solusi High School in Zimbabwe as well as Solusi University. She has also been an Adjunct lecturer at Rusangu University in Zambia. Part time lecturer at the University of Zambia. She is currently a full time lecturer at Eden University in Zambia. She is also a Pastor's Wife. They are currently saving under Midlands West Zambia Conference. She is a director of Women, Children and Health Ministries in Midlands West Zambia. Currently she is involved in Lecturing and Conference work in Midlands West Zambia Conference.

Citation: Linda Sibanda. "Team Ministry between Pastors and Shepherdesses: A Case Study of the Seventh Day Adventist Midlands Conference” International Journal of Humanities Social Sciences and Education (IJHSSE), vol 8,no.1, 2021, pp.25-34. doi:https://doi.org/10.20431/2349-0381.0801004.

Copyright: () 2021 Authors. This is an open-access article distributed under the terms of the Creative Commons Attribution License, which permits unrestricted use, distribution, and reproduction in any medium, provided the original author and source are credited. 